\title{
Ensuring Adequate Iron Status in Vegetarians and Vegans
}

\author{
Stewart D Rose* and Amanda J Strombom
}

Plant-Based Diets in Medicine, USA

Submission: June 18, 2019; Published: July 26, 2019

*Corresponding author: Stewart Rose, Plant-Based Diets in Medicine, 12819 SE 38th St, \#427, Bellevue, WA 98006, USA

\begin{abstract}
Many people, including some physicians, are concerned about iron deficiency anemia in patients consuming a plant-based diet. However, studies show that the risk of anemia in vegetarian and vegan patients is no greater than in omnivorous patients.

Plant foods contain only non-heme iron, whereas meat contains both the heme and non-heme iron. There used to be a concern that nonheme iron would be poorly absorbed resulting in iron deficiency anemia. However, non-heme is well absorbed in most vegetarian patients and vegan because other plant foods, containing substances such as vitamin $C$ and citric acid, can greatly enhance its absorption. Furthermore, nonheme iron absorption increases whenever iron stores are low.
\end{abstract}

Adequate iron levels can easily be maintained in the vegan patient with a little planning. Consuming foods high in iron along with foods that enhance non-heme iron absorption, will prevent iron deficiency anemia in vegan and vegetarian patients. Because both groups of foods are widely available, this should not be difficult to accomplish.

Patients that are already anemic can be treated by increasing their consumption of iron rich and iron enhancing foods. Supplements are sometimes required. In these cases, iron supplements can be prescribed in the same manner as with omnivorous patients.

Keywords: Anemia; Deficiency; Heme iron; Hepcidin; Iron; Non-heme iron; Plant-based diet; Supplements; Vegetarian; Vegan; Plant foods; Enterocytes; Macrophages; Synaptogenesis; Myelinization; Oxidative phosphorylation; Cytochromes, Sulfuric Proteins

\section{Introduction}

\section{Iron sources}

There are two types of iron in food: heme and non-heme iron. In animal products, $40 \%$ of the total iron content is heme iron and $60 \%$ non-heme iron [1]. Plant foods contain only non-heme iron.

Table 1: Sources of Iron in Plant Foods.

\begin{tabular}{|c|c|c|}
\hline Food & Serving Size & Iron (mg) \\
\hline Vegetables and Fruit: & & $2.0-3.4$ \\
\hline Spinach, cooked & $125 \mathrm{~mL}(1 / 2$ cup) & 2.4 \\
\hline Tomato puree & $125 \mathrm{~mL}(1 / 2$ cup) & 2.2 \\
\hline Edamame, baby soybeans, cooked & $125 \mathrm{~mL}(1 / 2$ cup) & 2.1 \\
\hline Asparagus, raw & 6 spears & 2 \\
\hline Hearts of palm, canned & $125 \mathrm{~mL}(1 / 2$ cup) & $1.3-1.9$ \\
\hline Potato with skin, cooked & $1 \mathrm{medium}$ & 1.7 \\
\hline Snow peas, cooked & $125 \mathrm{~mL}(1 / 2$ cup) & $1.5-1.7$ \\
\hline Turnip or beet greens, cooked & $125 \mathrm{~mL}(1 / 2$ cup) & 1.6 \\
\hline Prune juice & $125 \mathrm{~mL} \mathrm{(1/2} \mathrm{cup)}$ & \\
\hline
\end{tabular}

Many breakfast cereals and some breads are also fortified with iron [2].

Plant foods that naturally contain iron, are wholegrain cereals and breads; dried beans and legumes; dark green leafy vegetables; dried fruits; and nuts and seeds [3] (Table 1). 


\section{Advanced Research in Gastroenterology \& Hepatology}

\begin{tabular}{|c|c|c|}
\hline Apricots, dried & $60 \mathrm{~mL}(1 / 4$ cup $)$ & 1.6 \\
\hline Beets, canned & $125 \mathrm{~mL}(1 / 2$ cup $)$ & 1.6 \\
\hline Kale, cooked & $125 \mathrm{~mL}(1 / 2$ cup $)$ & 1.3 \\
\hline Green peas, cooked & $125 \mathrm{~mL}(1 / 2$ cup $)$ & 1.3 \\
\hline Tomato sauce & $125 \mathrm{~mL}(1 / 2$ cup) & 1.3 \\
\hline \multicolumn{3}{|l|}{ Grain Products: } \\
\hline Oatmeal, instant cooked & $175 \mathrm{~mL}(3 / 4$ cup $)$ & $4.5-6.6$ \\
\hline Cream of wheat, all types, cooked & $175 \mathrm{~mL}$ ( $3 / 4$ cup) & $5.7-5.8$ \\
\hline Cereal, dry all types & $\begin{array}{l}\text { 30g (check product label for serving } \\
\text { size) }\end{array}$ & $4.0-4.3$ \\
\hline Granola bar, oats, fruit and nut & $32 \mathrm{~g}(1$ bar $)$ & $1.2-2.7$ \\
\hline \multicolumn{3}{|l|}{ Legumes, nuts and seeds: } \\
\hline Tofu, cooked & $150 \mathrm{~g}(3 / 4$ cup $)$ & $2.4-8.0$ \\
\hline Soybeans, mature, cooked & $175 \mathrm{~mL}(3 / 4$ cup $)$ & 6.5 \\
\hline Lentils, cooked & $175 \mathrm{~mL}(3 / 4$ cup $)$ & $4.1-4.9$ \\
\hline Beans (white, kidney, navy, pinto, black, adzuki), cooked & $175 \mathrm{~mL}(3 / 4$ cup) & $2.6-4.9$ \\
\hline Pumpkin or squash seeds, roasted & $60 \mathrm{~mL}(1 / 4$ cup $)$ & $1.4-4.7$ \\
\hline Peas (chickpeas, black-eyed, split), cooked & $175 \mathrm{~mL}(3 / 4$ cup $)$ & $1.9-3.5$ \\
\hline Tempeh/fermented soy product, cooked & $150 \mathrm{~g}(3 / 4 \mathrm{cup})$ & 3.2 \\
\hline Meatless sausage, chicken, meatballs, fish sticks, cooked & $75 \mathrm{~g}(2.5 \mathrm{oz})$ & $1.5-2.8$ \\
\hline Baked beans, canned & $175 \mathrm{~mL}(3 / 4$ cup $)$ & 2.2 \\
\hline $\begin{array}{l}\text { Nuts (cashews, almonds, hazelnuts, macadamia, pistachio), without shell, } \\
\text { raw }\end{array}$ & $60 \mathrm{~mL}$ ( $1 / 4$ cup) & $1.3-2.2$ \\
\hline Sesame seeds, roasted & $15 \mathrm{~mL}(1 \mathrm{Tbsp})$ & 1.4 \\
\hline Meatless luncheon slices & $75 \mathrm{~g}(2.5 \mathrm{oz})$ & 1.4 \\
\hline Hummus & $60 \mathrm{~mL}(1 / 4$ cup $)$ & 1.5 \\
\hline Almond butter & $30 \mathrm{~mL}(2 \mathrm{Tbsp})$ & 1.1 \\
\hline
\end{tabular}

Source: Canadian Nutrient File 2015.

\section{Physiology and pathology}

Iron is a transition metal and has multiple functions in more than 180 biochemical reactions in the human body, including electron transport in redox reactions (cytochromes, sulfuric proteins), redox catalytic functions (cytochrome p450, catalase, peroxidase) and reversible storage and transport of 02 (hemoglobin, myoglobin). It also plays an important role in the production of neurotransmitters, and is essential in synaptogenesis and myelinization. Oxidative phosphorylation is the most critical biochemical pathway in which iron is involved [4-6].

Iron deficiency anemia usually develops slowly. As iron levels decline in the stores (iron deficiency) and in the circulation (iron restricted erythropoiesis), becoming insufficient for the full hemoglobinization of mature erythroblasts (iron deficiency anemia), the liver peptide hormone hepcidin is transcriptionally suppressed [7]. Indeed, serum hepcidin levels are significantly lower in young women with a negative iron balance compared with males and postmenopausal women, and are even undetectable in serum of individuals with iron deficiency anemia [8-10]. The decrease of hepcidin enhances iron release into plasma through ferroportin from both enterocytes and macrophages in the attempt to maintain normal transferrin [7].

\section{Absorption}

The amount of non-heme iron absorbed is primarily determined by the body's need for iron - people with the lowest iron stores will absorb more and excrete less $[2,11]$. Humans can adapt successfully to a wide range of iron requirements and intakes [12]. If iron intake is low, vegetarians adapt by excreting less fecal ferritin [11]. In pregnant women who need the most iron, absorption can increase by $60 \%$ relative to normal $[12,13]$. Non-heme iron is nearly as well absorbed as heme iron in people with very low iron stores [12]. There is apparently no advantage in storing more than a minimal amount of iron [14].

Absorption is increased as much as three to six-fold with the addition of $50 \mathrm{mg}$ of vitamin C per meal [3]. Vitamin C facilitates the conversion of $\mathrm{Fe}^{3+}$ (ferric) to $\mathrm{Fe}^{2+}$ (ferrous) iron, the form in which iron is best absorbed. This process is carefully regulated by the gut. Vegetarians typically have high intakes of vitamin $\mathrm{C}$ from a wide variety of fruits and vegetables. 
Other common organic acids such as citric and malic [15], as well as vitamin $A$ and $\beta$-carotene, also enhance non-heme iron absorption $[15,16]$.

This Vitamin C table shows that even modest servings of fruits and vegetables supply adequate vitamin $C$ to enhance iron absorption (Table 2).

Table 2: Selected Food Sources of Vitamin C.

\begin{tabular}{|c|c|c|}
\hline Food & $\begin{array}{c}\text { Milligrams (mg) } \\
\text { per serving }\end{array}$ & $\begin{array}{l}\text { Percent } \\
\text { (\%) DV* }\end{array}$ \\
\hline Red pepper, sweet, raw, $1 / 2$ cup & 95 & 158 \\
\hline Orange juice, $3 / 4$ cup & 93 & 155 \\
\hline Orange, 1 medium & 70 & 117 \\
\hline Grapefruit juice, $3 / 4$ cup & 70 & 117 \\
\hline Kiwifruit, 1 medium & 64 & 107 \\
\hline Green pepper, sweet, raw, $1 / 2$ cup & 60 & 100 \\
\hline Broccoli, cooked, $1 / 2$ cup & 51 & 85 \\
\hline Strawberries, fresh, sliced, $1 / 2$ cup & 49 & 82 \\
\hline Brussels sprouts, cooked, $1 / 2$ cup & 48 & 80 \\
\hline Grapefruit, $1 / 2$ medium & 39 & 65 \\
\hline Broccoli, raw, $1 / 2$ cup & 39 & 65 \\
\hline Tomato juice, $3 / 4$ cup & 33 & 55 \\
\hline Cantaloupe, $1 / 2$ cup & 29 & 48 \\
\hline Cabbage, cooked, $1 / 2$ cup & 28 & 47 \\
\hline Cauliflower, raw, $1 / 2$ cup & 26 & 43 \\
\hline
\end{tabular}

\section{Inhibitors of absorption}

There used to be some concern about tea consumption and iron absorption. However, tea consumption does not influence iron status in Western populations in which most people have adequate iron stores as determined by serum ferritin concentrations. Only in individuals with marginal iron status, may there be a negative association between tea consumption and iron status [17].

There has also been a theoretical concern about the larger intake of phytates that comes from following a plant-based diet inhibiting absorption of some minerals, such as iron. However, it turns out that the intestinal flora of vegetarians act to degrade phytate, thus allowing for good absorption of minerals. One recent study concludes that, "it was the vegetarians' microbiota that particularly degraded up to $100 \%$ phytate to myo-inositol phosphate products [18]."

While some studies have found that oxalic acid (present in spinach, silver beet and beetroot leaves) may inhibit iron absorption, recent studies suggest that its effects are relatively insignificant [19]. Calcium has also been considered an inhibitor of both heme and non-heme iron absorption, but recent research suggests that, over a long period of time, calcium has a limited effect on iron absorption (possibly due to an adaptive physiological response) [20] Nevertheless, it may be best to avoid consuming large calcium supplements with meals.

\section{Clinical considerations}

Vegetarians and vegans who eat a varied and well-balanced diet are not at any greater risk of iron deficiency anemia than nonvegetarians, even though iron stores of vegetarians may be lower than in non-vegetarians [3,21-23].

Iron deficiency anemia occurs in $5-12 \%$ of otherwise healthy premenopausal women $[24,25]$ and is usually due to menstrual loss, increased demands in pregnancy and breast feeding, or dietary deficiency [26]. Blood loss from the GI tract is the most common cause in adult men and postmenopausal women [27-32].

Gastrointestinal conditions, such as celiac disease and inflammatory bowel disease, as well as chronic kidney disease, cancer, and chronic heart failure increase the risk for anemia and iron deficiency [33-41]. Underlying conditions should be treated concurrently.

The diagnostic criteria for anemia in iron deficiency anemia vary between studies: Hgb less than 10-11.5 g/dl for women and less than $12.5-13.8 \mathrm{~g} / \mathrm{dl}$ for men. The lower limit of the normal range of hemoglobin concentration, for the laboratory performing the test, should therefore be used to define anemia [42].

For anemic patients, both the mean corpuscular volume (MCV) and the mean corpuscular hemoglobin concentration (MCHC) will also have values below the normal range for the laboratory performing the test. Reference range values for MCV and MCHC are 83-97 fL and 32-36 g/dL, respectively.

Serum ferritin concentration is a valuable test for iron deficiency anemia [43]. A serum ferritin concentration of less than $12 \mu \mathrm{g} / \mathrm{dl}$ is diagnostic of iron deficiency anemia [44]. However, elevated ferritin levels are usually due to causes such as acute or chronic inflammation, chronic alcohol consumption, liver disease, renal failure, metabolic syndrome, or malignancy rather than iron overload [45], so serum ferritin may be above $12-15 \mu \mathrm{g} / \mathrm{dl}$ in patients with iron deficiency anemia and concurrent chronic inflammation, malignancy, or hepatic disease. If the concentration is greater than $100 \mu \mathrm{g} / \mathrm{dl}$, iron deficiency anemia is almost certainly not present [44].

To avoid false negative results (high ferritin levels in spite of iron deficiency), an acute phase reaction should be excluded by taking a history and measuring the C-reactive protein or erythrocyte sedimentation rate [45].

The cornerstone of preventing iron deficiency in patients following a plant-based diet is to instruct patients to include plant foods high in iron in their diet. These foods can also be used to treat mild deficiencies while they can serve as an adjunct to iron supplementation. Patients should also be counseled to include iron absorption enhancers in the prevention and treatment of iron deficiency anemia.

Treatment of an underlying cause should prevent further iron loss, but all anemic patients should have iron supplementation 
both to correct anemia and replenish body stores [46]. This is achieved affordably with ferrous sulfate $200 \mathrm{mg}$ twice daily. Lower doses may be as effective and better tolerated $[47,48]$ and should be considered in patients not tolerating traditional doses. Other iron compounds (eg, ferrous fumarate, ferrous gluconate) or formulations (iron suspensions) may also be tolerated better than ferrous sulfate. Oral iron should be continued for 3 months after the iron deficiency has been corrected so that stores are replenished [49].

Intestinal iron absorption is limited. The maximum rate of absorption of $100 \mathrm{mg}$ of oral iron supplement is $20 \%$ to $25 \%$ and is reached only in the late stage of iron deficiency. Latent iron deficiency and iron deficiency anemia correspond to mean absorption rates of $10 \%$ and $13 \%$, respectively, whereas healthy males absorb 5\% and healthy females 5.6\% [49,50].

Dose-dependent gastrointestinal side effects of iron supplementation hinder compliance and result in nonadherence in up to $50 \%$ of patients [51]. For those intolerant or not responding to oral iron, three parenteral preparations are available [49].

\section{Discussion}

Patients following a plant-based diet, and their physicians, need not be concerned that a plant-based diet will lead to iron deficiency anemia any more than an omnivorous diet will. However, that doesn't mean that iron deficiency anemia shouldn't be tested for when indicated. Iron deficiency is prevalent in the general population; an average of $5.6 \%$ of the U.S. population met the criteria for anemia and $1.5 \%$ for moderate-severe anemia [52]. Menstruating and pregnant women are at particular risk [52].

The vegetarian and vegan patient should be instructed as to which plant foods are high in iron and how to enhance absorption. Plenty of foods that are high in iron can be chosen. If this is not enough and anemia results, then supplements are available and can be employed the same way as with omnivorous patients.

There are now several million Americans who follow either a vegan or vegetarian diet. Many physicians have started to prescribe a plant-based diet for the prevention and treatment of several diseases such as coronary artery disease and type 2 diabetes. By prescribing a diet that has ample iron-containing foods, along with the foods that enhance absorption, the physician can help ensure an adequate iron status in their patients following a plant-based diet.

\section{References}

1. Beard J, Dawson H, Piñero D (1996) Iron metabolism: a comprehensive review. Nutr Rev 54(10): 295-317.

2. Hurrell R, Egli I (2010) Iron bioavailability and dietary reference values. Am J Clin Nutr 91(5): 1461S-1467S.

3. Saunders A, Craig W, Baines S, Posen J (2013) Iron and vegetarian diets. Med J Aust 199(4 Suppl): S11-S16.

4. Clénin G (2017) The treatment of iron deficiency without anaemia (in otherwise healthy persons). Swiss Med Wkly 147: w14434.
5. Ganz T (2007) Molecular control of iron transport. J Am Soc Nephrol 18(2): 394-400.

6. Löffler G, Petrides P (1998) Biochemie und Pathobiochemie. (6 ${ }^{\text {th }}$ edn.), Berlin Heidelberg, Springer-Lehrbuch.

7. Camaschella C, Hoffbrand A, Hershko C (2016) Iron metabolism iron deficiency and disorders of haem synthesis. In: Hoffbrand V, Higgs D, Keeling D, Mehta A, (Eds.), Postgraduate Haematology. ( $7^{\text {th }}$ edn.), Oxford: Wiley-Blackwell.

8. Traglia M, Girelli D, Biino G, Campostrini N, Corbella M, et al. (2011) Association of HFE and TMPRSS6 genetic variants with iron and erythrocyte parameters is only in part dependent on serum hepcidin concentrations. J Med Genet 48(9): 629-634.

9. Galesloot T, Vermeulen S, Geurts-Moespot A, Klaver S, Kroot J, et al. (2011) Serum hepcidin: reference ranges and biochemical correlates in the general population. Blood 117(25): e218-225.

10. Camaschella C (2015) Iron deficiency: new insights into diagnosis and treatment. Hematology Am Soc Hematol Educ Program 2015: 8-13.

11. Hunt J (2003) Bioavailability of iron, zinc, and other trace minerals from vegetarian diets. Am J Clin Nutr 78(3 Suppl): 633S-639S.

12. Hunt J, Roughead Z (1999) Nonheme-iron absorption, fecal ferritin excretion, and blood indexes of iron status in women consuming controlled lactoovovegetarian diets for 8 wk. Am J Clin Nutr 69(5): 944-952.

13. Whittaker P, Barrett J (2001) The erythrocyte incorporation of absorbed non-haem iron in pregnant women. Br J Nutr 86(3): 323-329.

14. Siimes M, Refino C, Dallman P (1980) Manifestation of iron deficiency at various levels of dietary iron intake. Am J Clin Nutr 33(3): 570-574.

15. Gillooly M, Bothwell T, Torrance J, MacPhail A, Derman D, et al. (1983) The effects of organic acids, phytates and polyphenols on the absorption of iron from vegetables. Br J Nutr 49(3): 331-342.

16. García-Casal M, Layrisse M, Solano L, Baron M, Arguello F, et al. (1998) Vitamin $\mathrm{A}$ and beta-carotene can improve nonheme iron absorption from rice, wheat and corn by. J Nutr 128(3): 646-650.

17. Temme E, Van Hoydonck P (2002) Tea consumption and iron status. Eur J Clin Nutr 56(5): 379-386.

18. Markiewicz L, Honke J, Haros M, Świątecka D, Wróblewska B (2013) Diet shapes the ability of human intestinal microbiota to degrade phytate- in vitro studies. J Appl Microbiol 115(1): 247-259.

19. Storcksdieck S, Walczyk T, Renggli S, Hurrell R (2008) Oxalic acid does not influence nonhaem iron absorption in humans: a comparison of kale and spinach meals. Eur J Clin Nutr 62(3): 336-341.

20. Mølgaard C, Kaestel P, Michaelsen K (2005) Long-term calcium supplementation does not affect the iron status of 12-14-y-old girls. Am J Clin Nutr 82(1): 98-102.

21. Craig W (1994) Iron status of vegetarians. Am J Clin Nutr 59(5 Suppl): 1233S-1237S

22. Haddad E, Berk LKJ, Hubbard R, Peters W (1999) Dietary intake and biochemical, hematologic, and immune status of vegans compared with nonvegetarians. Am J Clin Nutr 70(3 Suppl): 586S-593S.

23. Elorinne A, Alfthan G, Erlund I, Kivimäki H, Paju A, et al. (2016) Food and Nutrient Intake and Nutritional Status of Finnish Vegans and NonVegetarians. PLoS One 11(2): e0148235.

24. (1992) World Health Organization. Maternal Health and Safe Motherhood Programme \& World Health Organization. Nutrition Programme. The Prevalence of Anaemia in Women: A Tabulation of Available Information. ( $2^{\text {nd }}$ edn.), Geneva, USA. 
25. Looker A, Dallman P, Carroll M, Gunter E, Johnson C (1997) Prevalence of iron deficiency in the United States. JAMA 277(12): 973-976.

26. Allen L (1997) Pregnancy and iron deficiency: unresolved issues. Nutr Rev 55(4): 91-101.

27. Kepczyk T, Kadakia S (1995) Prospective evaluation of gastrointestinal tract in patients with iron-deficiency anemia. Dig Dis Sci 40(6): 12831289.

28. Rockey D, JP C (1993) Evaluation of the gastro-intestinal tract in patients with iron-deficiency anemia. New Eng J Med 329(23): 16911695.

29. Cook I, Pavli P, Riley JW, Goulston K, Dent $O$ (1986) Gastrointestinal investigation of iron deficiency anaemia. Br Med J (Clin Res Ed) 292(6532): 1380-1382.

30. Zuckerman G, Benitez J (1992) A prospective study of bidirectional endoscopy (colonoscopy and upper endoscopy) in the evaluation of patients with occult gastrointestinal bleeding. Am J Gastroentero $87(1): 62-66$.

31. Hardwick R, Armstrong C (1997) Synchronous upper and lower gastrointestinal endoscopy is an effective method of investigating irondeficiency anaemia. Br J Surg 84(12): 1725-1728.

32. James M, Chen C, Goddard W, Scott B, Goddard A (2005) Risk factors for gastrointestinal malignancy in patients with iron-deficiency anaemia. Eur J Gastroenterol Hepatol 17(11): 1197-1203.

33. Hershko C, Hoffbrand A, Keret D, Souroujon M, Maschler I, et al. (2005) Role of autoimmune gastritis, Helicobacter pylori and celiac disease in refractory or unexplained iron deficiency anemia. Haematologica 90(5): 585-595

34. Corazza G, Valentini R, Andreani M, D’Anchino M, Leva M, et al. (1995) Subclinical coeliac disease is a frequent cause of iron-deficiency anaemia. Scand J Gastroenterol 30(2): 153-156.

35. Kulnigg S, Gasche C (2006) Systematic review: managing anaemia in Crohn's disease. Aliment Pharmacol Ther 24(11-12): 1507-1523.

36. Gasche C (2000) Anemia in IBD: the overlooked villain. Inflamm Bowel Dis 6(2): 142-150.

37. De Nicola L, Minutolo R, Chiodini P, Zamboli P, Cianciaruso B, et al (2010) Prevalence and prognosis of mild anemia in non-dialysis chronic kidney disease: a prospective cohort study in outpatient renal clinics. Am J Nephrol 32(6): 533-540.
38. Minutolo R, Locatelli F, Gallieni M, Bonofiglio R, Fuiano G, et al. (2013) Anaemia management in non-dialysis chronic kidney disease (CKD) patients: a multicentre prospective study in renal clinics. Nephrol Dial Transplant 28(12): 3035-3045.

39. Baribeault D, Auerbach M (2011) Iron replacement therapy in cancerrelated anemia. Am J Health Syst Pharm 68(10 Suppl 1): S4-S14.

40. Jankowska E, Rozentryt P, Witkowska A, Nowak J, Hartmann O, et al. (2010) Iron deficiency: an ominous sign in patients with systolic chronic heart failure. Eur Heart J 31(15): 1872-1880.

41. Klip I, Comin-Colet J, Voors A, Ponikowski P, Enjuanes C, et al. (2013) Iron deficiency in chronic heart failure: an international pooled analysis. Am Heart J 165(4): 575-582.

42. Goddard A, James M, McIntyre A, Scott B (2011) Guidelines for the management of iron deficiency anaemia. Gut 60(10): 1309-1316.

43. Guyatt G, Oxman A, Ali M, Willan A, Mcllroy W, et al. (1992) Laboratory diagnosis of iron-deficiency anemia: an overview. J Gen Intern Med $7(2): 145-153$.

44. Cook J, Baynes R, Skikne B (1992) Iron deficiency and the measurement of iron status. Nutr Res Rev 5(1): 198-202.

45. Koperdanova M, Cullis J (2015) Interpreting raised serum ferritin levels. BMJ 351: h3692.

46. Smith A (1997) Prescribing iron. Prescribers' J 37: 82-87.

47. Crosby W, O’Neil-Cutting M (1984) A small dose iron tolerance test as an indicator of mild iron deficiency. JAMA 251(15): 1986-1987.

48. Joosten E, Vander Elst B, Billen J (1997) Small-dose iron absorption testing in anemic and non-anemic elderly hospitalised patients. Eur J Haematol 58(2): 99-103.

49. Jimenez K, Kulnigg-Dabsch S, Gasche C (2015) Management of Iron Deficiency Anemia. Gastroenterol Hapatol (NY) 11(4): 241-250.

50. Werner E, Kaltwasser J, Ihm P (1976) Intestinal absorption from therapeutic iron doses (author's transl). Arzneimittelforschung 26(11): 2093-2100.

51. Tolkien Z, Stecher L, Mander A, Pereira D, Powell J (2015) Ferrous sulfate supplementation causes significant gastrointestinal side-effects in adults: a systematic review and meta-analysis. PLoS One 10(2): e0117383.

52. Le C (2016) The Prevalence of Anemia and Moderate-Severe Anemia in the US Population (NHANES 2003-2012). PLoS One 11(11): e0166635.

\section{Your next submission with JuniperPublishers will reach you the below assets}

- Quality Editorial service

- Swift Peer Review

- Reprints availability

- E-prints Service

- Manuscript Podcast for convenient understanding

- Global attainment for your research

- Manuscript accessibility in different formats ( Pdf, E-pub, Full Text, audio)

- Unceasing customer service

Track the below URL for one-step submission https://juniperpublishers.com/online-submission.php 